\section{Virus titrations using trypsin modified erythrocytes}

\section{K. F. SHORTRIDGE AND L. Y. HU Department of Micro- biology, University of Hong Kong, Pathology Building, Queen Mary Hospital Compound, Hong Kong}

Because of its relative ease of operation the haemagglutination inhibition (HAI) test has been widely used in diagnostic virus serology for detecting specific antibody to haemagglutinating viruses. Erythrocyte species of animal origin are used more frequently than human group ' $O$ ' cells in haemagglutination (HA) and HAI tests because they are usually more sensitive to agglutination by certain viruses and, as well, the patterns produced are generally easier to read. Animal erythrocytes, however, suffer the drawback that, in the HAI test, human sera need to be treated with packed cells to remove natural agglutinins as their presence might otherwise obscure low or even high levels of antibody. Agglutinin titres for chicken, gander, guinea pig, monkey, and rat erythrocytes in 20 randomly chosen sera originally submitted for biochemical examination are shown in Table 1.

Table 1 Agglutinin content of 20 randomly selected human sera belonging to $O, A, B$, and $A B$ blood groups for animal erythrocytes often used in virus haemagglutination titrations

\begin{tabular}{llc}
\hline Erythrocyte & \multicolumn{2}{l}{ Serum agglutinin titres* } \\
\cline { 2 - 3 } & Titre range & Geometric mean titre \\
\hline Chicken & $<5-120 \dagger$ & 11 \\
Guinea pig & $10-320$ & 52 \\
Monkey & $20-160$ & 56 \\
Rat & $40-640$ & 158 \\
Gander & $15-480$ & 35 \\
Trypsinised gander $\ddagger$ & $40-10240$ & 190 \\
\hline
\end{tabular}

*Sera diluted in $50 \mu \mathrm{l}$ volumes to which were added $50 \mu 10.5 \%$ (vol/ vol) erythrocyte suspensions and the patterns read after $30 \mathrm{~min}$ at room temperature.

+Sera of titre $<5$ were assigned a value of 5 for calculation of geometric mean titre.

¥The use of trypsinised gander erythrocytes is described further in the text and in Table 3.

Recent studies have shown that rubella and a number of arboviruses are rendered susceptible to agglutination by human group $O$ erythrocytes after modification of the cell surface by trypsin (Biddle, 1970; Shortridge and $\mathrm{Hu}, 1974$; 1976; Shortridge, 1976). The use of these trypsinised (TrO) cells in the HAI test has the advantage of circumventing the

Received for publication 12 April 1977 agglutinin adsorption step, and they have been applied diagnostically for detecting specific antibody against rubella virus (Nelson et al., 1974) and the arboviruses, Japanese encephalitis and Ross River (Shortridge and $\mathrm{Hu}, 1974 ; 1976$ ).

Against this background human $\mathbf{O}$ and TrO cells were examined for their susceptibility to agglutination by a range of known haemagglutinating and non-haemagglutinating viruses. Trypsinisation of the cells was effected with 1:250 trypsin (Difco Laboratories, Detroit, USA) at a concentration of $1 \mathrm{mg} / \mathrm{ml}$ for one hour at $37^{\circ} \mathrm{C}$ as described (Shortridge and $\mathrm{Hu}, 1974)$. After washing in Tris-saline buffer (0.15 $\mathrm{M} \mathrm{NaCl}$ in $0.01 \mathrm{M}$ tris (hydroxy methyl) aminomethane-hydrochloride, $\mathrm{pH} 7.5$ ) the cells were prepared as $0.5 \%$ ( $\mathrm{vol} / \mathrm{vol})$ suspensions in $0.2 \mathrm{M}$ phosphate buffer at pH 5.85, 6.0, 6.2, 6.4, 6.6, 6.8, and 7.0. Untreated cells were prepared in a similar manner. Erythrocyte species commonly employed for detecting the HA activity of haemagglutinating viruses (see Table 2) were prepared according to the protocol of the American Public Health Association (1969). HA and HAI tests were carried out in microtrays with volumes adapted to $100 \mu \mathrm{l}$ final volume as reported by Shortridge and $\mathrm{Hu}$ (1974). Some of the viruses used in this study were generously provided by Drs F. Brown, W. K. Chang, B. Johnson, $\mathrm{M}$. $\mathrm{Ng}$, and by $\mathrm{M}$. W. Lam.

TrO cells were susceptible to agglutination by representative togaviruses in line with previous findings (Shortridge and Hu, 1974; 1976). This behaviour was observed well with the Brazil, New Jersey, and Indiana strains of vesicular stomatitis virus (VSV), each exhibiting HA titres approximately 60 - and 20 fold greater than were observed with untreated $O$ cells and gander cells, respectively. In the case of the other RNA-enveloped viruses, namely, those belonging to the myxo- and paramyxovirus groups, only mumps and parainfluenza type 3 viruses agglutinated TrO cells significantly in comparison with the commonly used guinea pig cells. Vaccinia virus and recognised non-haemagglutinating herpes and picornaviruses were unable to agglutinate the human $\mathbf{O}$ cells after trypsinisation. However, the TrO cells were significantly agglutinated by certain adenoviruses in accord with some earlier observations. made on these viruses (Shortridge and Norrby, 1973). It is of interest to note that the presence or absence of a virus envelope did not appear to be associated with the ability of a virus to agglutinate TrO cells.

The TrO cells were optimally agglutinated at $\mathrm{pH}$ 5.85 and 6.0 . This is well illustrated with VSV, the most sensitive of the viruses investigated (Table 3 ). When gander cells were trypsinised in the manner described for human $O$ cells they, too, showed increased susceptibility to agglutination by VSV; 
Table 2 Haemagglutination of trypsinised human group $O(T r O)$ erythrocytes by representative viruses

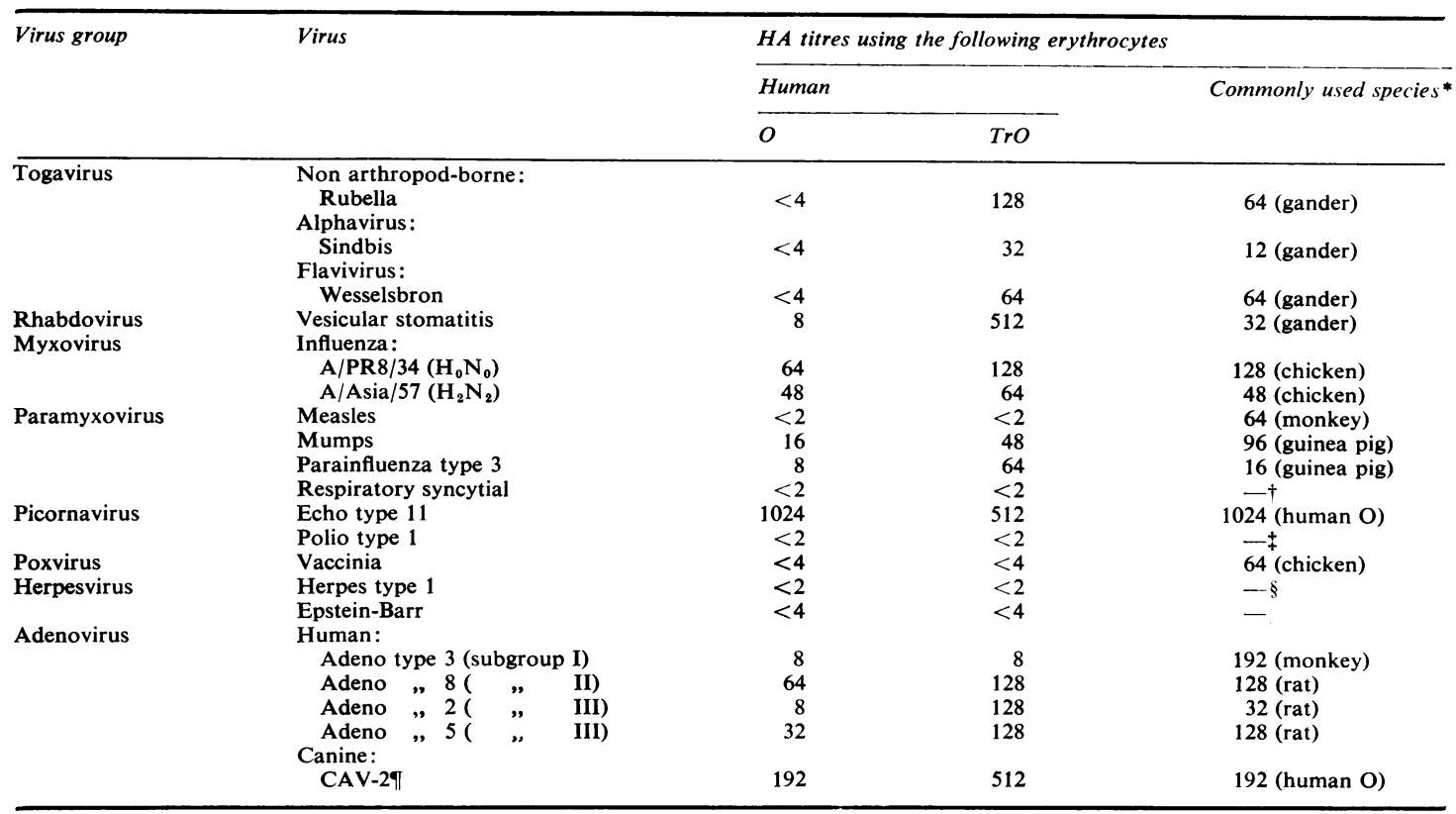

*Background titres are given for comparison with those obtained using human erythrocytes.

Non-haemagglutinating viruses; the activity of each preparation was as follows:

$+10^{3} \mathrm{TCID}_{\mathrm{so}} / \mathrm{ml}$ in HEp-2 cells.

$\$ 10^{5} \mathrm{TCID}_{50} / \mathrm{ml}$ in monkey kidney cells.

$\$ 10^{4 \cdot 6} \mathrm{ph}$. . .u. $/ \mathrm{ml}$ on the chorioallantoic membrane of the embryonated egg.

$\| 5 \times 10^{7}$ particles by electron microscopy in a P3HR-1 cell culture fluid concentrate.

T CAV-2, canine adenovirus type 2, formerly known as infectious canine laryngotracheitis virus.

Table 3 Haemagglutination of gander and human group $O$ erythrocytes (normal and trypsinised) by vesicular stomatitis virus

\begin{tabular}{|c|c|c|c|c|c|c|c|c|c|c|c|c|c|c|c|}
\hline \multicolumn{4}{|c|}{ pH 5.85} & \multicolumn{4}{|c|}{$p H 6.0$} & \multicolumn{4}{|c|}{$p H 6 \cdot 2$} & \multicolumn{4}{|c|}{$p H 6 \cdot 4-7 \cdot 0$} \\
\hline G & $\operatorname{Tr} G$ & $O$ & $\operatorname{Tr} O^{*}$ & $G$ & $\operatorname{TrG}$ & $O$ & $\operatorname{TrO}$ & $G$ & $\operatorname{Tr} G$ & $O$ & $\operatorname{TrO}$ & $G$ & $\operatorname{Tr} G$ & $O$ & $\operatorname{Tr} O$ \\
\hline$\overline{20}$ & 80 & 10 & 480 & 80 & 240 & $<10$ & 80 & 10 & 30 & $<10$ & 40 & $<10$ & $<10$ & $<10$ & $<10$ \\
\hline
\end{tabular}

*G, gander; TrG, trypsinised gander; O, human group O; TrO, trypsinised human group O.

however, such cells were highly sensitive to natural agglutinins in human sera (Table 1), thereby negating their potential use in the HAI test.

In the HAI test as applied to the detection of mumps virus antibody, TrO and guinea pig cells were of comparable efficiency, the titres obtained being similar to those recorded using the surface or $\mathrm{V}$ antigen by complement fixation. Representative results are given in Table 4. Sera for which titrations were to be performed using TrO cells were not adsorbed with packed cells as there were no natural agglutinins to obscure antibody.

Follow-up studies employing rubella virus showed that, after trypsinisation, cord and 5-day-old group $O$ erythrocytes were generally more susceptible to agglutination than were adult erythrocytes which were used in this study. Untreated erythrocytes were separated into four fractions by centrifugation through phthalate ester gradients (Danon and Marikovsky, 1964). Each fraction showed increased agglutinability after trypsinisation, and this was strongest in the uppermost light fraction, particularly with cord and 5-day-old erythrocytes, suggesting that reticulocytes are important in this phenomenon.

The findings reported here show that trypsin modified erythrocytes can be of practical use in the diagnostic virus laboratory. There are many apparently non-haemagglutinating viruses whose identification and serology often require tedious and expensive laboratory procedures. The topography of 
Table 4 Use of trypsinised (TrO) cells for detecting mumps virus antibody in the HAI test

\begin{tabular}{|c|c|c|c|c|c|}
\hline \multirow[t]{2}{*}{ Specimen } & \multirow[t]{2}{*}{ Serum sample } & \multicolumn{2}{|c|}{ HAI titres using the following cells: } & \multicolumn{2}{|c|}{$\begin{array}{l}\text { Complement fixation titres using the following } \\
\text { antigenst }\end{array}$} \\
\hline & & Guinea pig & $\operatorname{TrO}$ & $V$ antigen & $S$ antigen \\
\hline PKL & $\begin{array}{l}\text { Acute } \\
\text { Convalescent }\end{array}$ & $\begin{array}{l}10^{*} \\
40\end{array}$ & $\begin{array}{l}10^{*} \\
40\end{array}$ & $\begin{array}{r}5 \\
80\end{array}$ & $\begin{array}{l}10 \\
40\end{array}$ \\
\hline \multirow[t]{2}{*}{ WCH } & Acute & 10 & 10 & 5 & $\begin{array}{r}40 \\
5\end{array}$ \\
\hline & Convalescent & 60 & 40 & 80 & 320 \\
\hline \multirow[t]{2}{*}{ MCL } & Acute & 40 & 40 & 160 & 20 \\
\hline & Convalescent & 320 & 640 & 640 & 80 \\
\hline
\end{tabular}

*Sera treated with receptor destroying enzyme to inactivate non-specific inhibitor.

† Results of antibody detection by complement fixation for comparison.

the erythrocyte is complex, containing many determinants that react with diverse macromolecules (for example, Pardoe et al. (1971)). Appropriate modification of the erythrocyte surface by enzymic or chemical treatment may ultimately lead to the establishment of simpler detection and quantitative procedures for such viruses.

\section{References}

American Public Health Association (1969). Diagnostic Procedures for Viral and Rickettsial Infections, 4th edition, edited by E. H. Lennette and N. J. Schmidt. American Public Health Association, New York.

Biddle, F. (1970). The unmasking of receptors for rubella virus by trypsinization of red cells. Microbios, 3, 255260.

Danon, D., and Marikovsky, Y. (1964). Determination of density distribution of red cell population. Journal of Laboratory and Clinical Medicine, 64, 668-674.
Nelson, B. N., Quirin, E. P., and Inhorn, S. L. (1974). Compatibility of trypsin-modified human erythrocytes in the rubella hemagglutination-inhibition test employing three serum treatment procedures. Applied Microbiology, 27, 767-770.

Pardoe, G. I., Uhlenbruck, G., and Reifenberg, U. (1971). Structural studies of red cells: immunochemistry of the $\mathbf{M}, \mathbf{N}$ and related antigens and of the myxoviral receptors. Medical Laboratory Technology, 28, 255-283.

Shortridge, K. F. (1976). Haemagglutination of trypsin modified erythrocytes by chagres virus. Archives of Virology, 52, 181-186.

Shortridge, K. F., and Hu, L. Y. (1974). Trypsinized human group $O$ erythrocytes as an alternative hemagglutinating agent for Japanese encephalitis virus. Applied Microbiology, 27, 653-656.

Shortridge, K. F., and Hu, L. Y. (1976). A note on the use of trypsinized human group $O$ erythrocytes in arbovirus titrations. American Journal of Tropical Medicine and Hygiene, 25, 486-488.

Shortridge, K. F., and Norrby, E. (1973). Studies on adenovirus receptors on red cells. Acta Pathologica et Microbiologica Scandinavica, 81B, 264-266. 